\title{
Robert Wood Johnson Foundation Nurse Faculty Scholars Program Leadership Training
}

Jacquelyn C. Campbell, PhD, RN, FAAN

Professor and Anna D. Wolf Chair, Johns Hopkins School of Nursing

National Program Director, Robert Wood Johnson Foundation Nurse Faculty Scholars Program

Baltimore, MD

Angela Barron McBride, PhD, RN, FAAN, FNAP, ANEF

Distinguished Professor and University Dean Emeritus, Indiana University School of Nursing

National Advisory Committee Chair, Robert Wood Johnson Foundation Nurse Faculty Scholars

Program

Indianapolis, IN

LuAnn Etcher, PhD, RN

Assistant Professor

Yale University School of Nursing

Robert Wood Johnson Foundation Nurse Faculty Scholars Alumna

JAHF \& Atlantic Philanthropies Claire M. Fagin Fellow, 2008-2010

Katie Deming

Deputy Director, Robert Wood Johnson Foundation Nurse Faculty Scholars Program

Johns Hopkins University School of Nursing

Baltimore, MD

Contact Information

Katie Deming

525 N. Wolfe Street, Room 441

Baltimore, MD 21205

443-287-6559

$\underline{\text { Kdeming1@jhu.edu }}$

This is the author's manuscript of the article published in final edited form as:

Campbell, J. C., McBride, A. B., Etcher, L., \& Deming, K. (2017). Robert Wood Johnson Foundation Nurse Faculty Scholars program leadership training. Nursing Outlook. https://doi.org/10.1016/j.outlook.2017.02.003 


\section{Abstract}

The Robert Wood Johnson Foundation Nurse Faculty Scholars program provided research funding, release time and leadership training to a selected group of junior faculty. This article describes the actual leadership training, including its development, domains addressed, learning strategies used to deliver content, and ongoing evaluation procedures. The leadership trainingwhich combined learning activities at their home institutions with in-person didactic and interactive sessions with notable leaders in nursing and other disciplines-was extremely useful, according to scholars' evaluations.

Key words: nursing; faculty development; leadership training; Outward Bound Training Model; Integrated Scholar Model; Robert Wood Johnson Foundation 
As fully described in the first article of this issue, the Robert Wood Johnson Foundation Nurse Faculty Scholars program (RWJF NFS) was created in order to address the nursing shortage through the development of the next generation of national leaders in academic nursing via the provision of research funding, release time and leadership training to a cadre of promising junior nursing faculty. The American Association of Colleges of Nursing (AACN) conducted a survey in 2014 that called attention to a 6.9 percent national nurse faculty vacancy rate with 89.6 percent of these vacancies in faculty positions that required or preferred $\mathrm{PhD}$ (AACN, 2014). Lack of preparedness for the faculty role and lack of professional development in academic settings have been linked to reduced faculty success and attrition (Anderson, 2009; Baker \& Baker, 2010; Davis, 2015; Derby-Davis, 2014; Field, 2012; Mobily, 1991). These two factors have the potential to be successfully ameliorated, at least in part, through academic nursing leadership training programs.

In order to be successful as a $21^{\text {st }}$ century nurse scholar and academic, today's nursing faculty must possess the skills necessary to function competitively within often challenging academic institutional environments. Today's complex fiscal issues necessitate new and innovative ways to recruit, vet and retain faculty, as well as foster and incentivize productivity and excellence in clinical practice, research, academic teaching performance and service (Reece, Nugent, Wheeler, \& Smith, 2008). Therefore, leadership training programs for nursing faculty that focus on the development of skills required for sustained high-level productivity in academia are imperative for today's faculty to succeed. Ideally, these programs would address: personal development; interdisciplinary collaboration to promote research and scholarship; management skills for academic leadership; skills for leadership in health policy and clinical practice arenas; teaching excellence; as well as leadership in the community, profession and on boards (Conn, 
Porter, McDaniel, Rantz, \& Maas, 2005; Fagin, Franklin, Regenstreif, \& Huba, 2006; Froman, Hall, Shah, Bernstein, \& Galloway, 2003; McBride, 2010).

Successful leadership training programs in nursing are multidimensional and purposefully individualized. They include didactic work, as well as components that are interactive and experiential (Fagin et al., 2006; Miller et al., 2006; Millett, Millett, \& Kevelson, 2015; Wilson, Crooks, Day, \& Dawson, 2014). In the Robert Wood Johnson Foundation Nurse Faculty Scholars program, the leadership development was individualized through the use of well-formulated collaboratively developed and periodically updated Individual Development Plans (IDP) (see description in the first article in this issue) for each participant. This multifaceted, individualized approach enhances development and mastery in all faculty domains, preparing nurse faculty to emerge from the training program with the necessary underpinning of knowledge, skills, and expertise needed for long-term success and sustainability in academia. The overall goal and objective of a leadership training program in nursing is to produce wellformed and well developed nurse faculty who are fully equipped for sustained success in the faculty role and who are able to rise to meet the competing challenges and complex demands inherent in $21^{\text {st }}$ century academia.

In academe, the Doctor of Philosophy $(\mathrm{PhD})$ is the highest academic degree (AACN, 2010). It is the $\mathrm{PhD}$ scientist who is tasked with passing the values, standards, and practices of science on to the next generation of scientists. While the pursuit of science alone is a hefty responsibility to uphold (less than $1 \%$ of nurses hold a $\mathrm{PhD}$ ), it is but only one of the competing roles and expectations of tenure-earning junior nurse faculty. Junior nurse faculty are faced with the fallout of our nation's nurse faculty shortage; specifically, heavier teaching loads, greater number of students, and increased committee workload. These increased demands result in less 
time for scholarly activities--seeking funding, carrying out the proposed research, analyzing the data, disseminating findings-yet these time-consuming activities are required in order to achieve tenure. Pressures imposed by the tenure clock, shrinking university budgets, as well as reduced research funding have also significantly contributed to attrition and a tenure-track junior nurse faculty shortage (AACN, 2015; Garand et. al., 2010).

The Robert Wood Johnson Foundation Nurse Faculty Scholars program was created in order to help address our nation's nursing faculty shortage through the development of the next generation of national leaders in academic nursing. The goal of the three-year award was to facilitate the academic career success of tenure-track junior nurse faculty through interdisciplinary mentoring and leadership development. Senior nurse and interdisciplinary leaders from across the nation facilitated the program which was focused on scholars' growth in the following areas: personal development; leadership skills for research and scholarship; management skills for academic leadership; leadership in health policy and translation of research to nursing practice; and skills for teaching excellence and leadership in the bigger picture of nursing education. The program was designed to achieve the goals through mentorship (see McBride et al., this issue), research funding and release time, and leadership training. The purpose of this article is to describe the leadership training component of the program, its development and the formative evaluation process used for continuous improvement, in order to provide those concerned with developing leadership training at their own institutions with some sense of what they, too, might include should they wish to move in that direction.

\section{Development of the Leadership Training}

A critical milestone in the development of the RWJF Nurse Faculty Scholars program was a retreat held in January 2008 with the interdisciplinary National Advisory Committee 
(NAC) (see Table 1, Campbell et al., this issue), the RWJF Program Officer (at that time Jeane Ann Grisso, professor emeritus at the University of Pennsylvania), and the National Program Director and Deputy Director. The aim of the retreat was to further develop and finalize the program's selection and recruitment process and to develop the leadership training. We had limited time to develop the training (and selection process), as our first cohort of RWJF scholars was to begin their program in September 2008. It was decided that rather than adopt a particular theory or model of leadership or leadership training, we would develop and work from certain assumptions to shape a program that was specific to academic nursing.

The assumptions that were agreed upon implicitly if not explicitly at that first retreat included the following: 1) academic leadership training had some overlap with business and management leadership (where most models originate) but had to have its own distinct elements; 2) interdisciplinarity was an important and increasing reality and necessity in practice, research, education and policy; yet leadership in nursing academia has a distinct scientific and clinical orientation, as does the discipline of nursing; 3 ) nursing is a gendered profession and therefore we took lessons from Eagly and Carli's Through the Labyrinth (2007), the HERS Leadership Institutes for Women in Higher Education (https://hersnet.org/institutes/) and also from our own male scholars and male nursing NAC members about the particular challenges for men in nursing (see Brody et al., this issue); 4) the need for increased diversity in the nursing workforce and therefore, among nursing students and nursing faculty, as well as increased inclusion is a reality and imperative in today's increasingly diverse world (see article by Thompson, Adams, \& Campbell, this issue); 5) nursing has an important obligation to decrease health inequities and improve health and health care in terms of health policy formation as well as research, practice and education; 6) academic leadership development means broadening junior faculty’s 
perspective from a concern only about their own development in scholarship, teaching, service and practice - to a view that encompasses the welfare and quality of the school and the university; 7) and work-life balance is a challenge all nursing faculty face with junior faculty who often have young children perhaps having the greatest challenges, particularly in academic settings where the push for publications and grant submissions never ends. The process of developing the leadership training was intense but highly collaborative and fully participatory with each of the participants bringing their own interdisciplinary intellectual roots.

In order to develop the leadership training, we used a curriculum matrix that spelled out a) the general domain of leadership training we wanted to address; b) the topics/modules within each domain, with competencies to be mastered; c) content at the two levels (institutional or national) of the leadership training where and by what means the competency would be acquired (e.g., through RWJF NFS or by other organization and by whom and with what approach); and d) the metric by which achievement of the competency is to be measured. Table 1, Curriculum Matrix describes the six domains and Table 2 gives one exemplar of a Topic or Module of the five to eight modules in each of the domains. We used the curriculum matrix to guide the development of the learning objectives for each of the RWJF NFS in-person leadership meetings, any supplemental webinars or other distance learning strategies, and assignments given to the scholars to fulfill at their own institution.

The National Level leadership training content was presented at the two day leadership training meetings every spring as well as the leadership training day held before the National Meeting every fall. In addition, one or two webinars were held each year for content we felt was possible to present and master in an online webinar format or we felt was needed to augment or 
follow up on content presented at the meetings. For example, we noticed at one National Meeting that many scholars were struggling with the complexities of intervention design, so a webinar was developed with several primary mentors who are expert in that area serving as speakers. Some content was augmented through "homework" such as an assignment to become part of a school of nursing (SON), university or community organization strategic planning process in the six months before that topic was addressed. The assignment included reflecting on and sharing lessons learned from that experience in light of the content on the topic presented at the subsequent leadership meeting. There were also reading assignments sent out before the meetings. All content was repeated once every three years since the meetings involved three cohorts of current scholars. The curriculum matrix was updated annually at the NAC and staff meetings held after the National Meetings. Evaluation input from scholars after each leadership training was used to shape and improve the content, presentation and presenters each time that topic was offered. (see section on formative evaluation below). Metrics were evaluated through scholar quarterly reports and other strategies reported in the Campbell et al. program overview article this issue.

\section{Orientation: The Initial Leadership Training}

The initial leadership training for each cohort occurred at the one and a half day Orientation Meeting attended by incoming Nurse Faculty Scholars and their primary mentors. This leadership training addressed the domain of Personal Development: "Through national leadership training, as well as opportunities identified locally and regionally, the RWJF NFS program guides scholars in career planning, developing self-awareness, managing time and energy, sustaining career optimism, thriving in changing conditions, achieving work-life balance 
including personal health promotion, and expanding their communication skills" (see Table 1 for an abbreviated curriculum matrix). The overall objectives of the Orientation Meeting were: To assess and plan for one's own trajectory of leadership in academic nursing; to understand the important elements of making a commitment to full career development in academic nursing; to increase understanding of mentee and mentor relationships and build the foundation for effective mentee-mentor relationships in academia; to develop self-knowledge about leadership style, including personality, strengths and limitations; to refine individual goals and plans for the Nurse Faculty Scholars experience; to get to know and learn from NFS peers as an important component of developing a network of colleagues for ongoing professional development and support

The first phase of that training included both formal presentations and interactive activities. The more interactive component included a small group orientation to the use of the RWJF NFS Individual Development Plan (IDP, described in the Program Overview article, this issue), where scholars had an opportunity for individualized feedback on their IDP goals. In another session led by a Myers-Briggs Type Indicator (MBTI) trained Professional, results and meanings were discussed regarding each scholar's profile on the MBTI. The MBTI profile assessment discloses psychological preferences on how people perceive the world and make decisions. Profiles were completed as homework and were submitted and reviewed ahead of time by the MBTI trained professional prior to arrival at the meeting. Primary mentors had some concurrent programming geared just to them; this included an exchange about effective mentoring with several NAC members (Angela Barron McBride, Nancy Fugate Woods, and Spero Manson) in which the focus was on setting expectations, answering questions and sharing lessons learned about successful mentoring. 
The first formal presentation, delivered by National Program Director Jacquelyn Campbell, provided an overall framework and was entitled "Surviving and Thriving: The Integrated Scholar Model" (Campbell \& Sharps, 2016). This presentation used an integrated scholar model to examine how the overlapping faculty roles of research/scholarship, teaching and service/practice can be powered by passion for an area of excellence and expertise (see Figure 1). In this model, efforts are synergized for maximum impact via collaborative mentoring and a team approach to activities. The presentation also paid attention to issues of diversity and inclusion across domains and using one's research to address issues of health inequity. The second address was by NAC Chair Angela Barron McBride who elaborated on key career stages and how to sustain career optimism (each new scholar also received a copy of her 2011 book The Growth and Development of Nurse Leaders to read before the meeting). The third major presentation, led by NAC members Nancy Fugate Woods and Spero Manson, discussed how to mentor and be mentored. In later years, it included an interactive session whereby each scholar and primary mentor separately completed the Investigator Needs Assessment then compared judgments (see Appendix A of the McBride et al. article on mentoring, this issue) and discussed where their perceptions overlapped and diverged.

This formal programming was followed by an intensely experiential leadership training led by professionals in a three-day version of the Outward Bound (OB) Outdoor Leadership Course (http://www.outwardbound.org/course-list/2015-outdoor-leadership-courses/) tailored to the RWJF NFS program and attended by the National Program Director. The Outward Bound objectives were as follows: a) To develop leadership skills through high-impact experiences that are awe-inspiring and challenging; b) To develop team awareness and team skills for improved performance; and c) To develop greater awareness and understanding of leadership styles 
through challenges designed to increase ambiguity and stress in the leadership realm. The other goal of the $\mathrm{OB}$ experience was to create rapid yet genuine bonding among the scholars in each cohort thus contributing to their becoming a strong network for peer mentorship, mutual support and collaborative productivity for the entirety of their academic nursing career.

A network analysis conducted as part of the program evaluation will be fully described in a forthcoming article. In brief, the analysis showed that two thirds (55) of the 89 scholars (of 90 total scholars and alumni) who responded were part of a close and enduring network that had published together over time. Twenty other scholars were part of a smaller but similarly close network that had also published together. Four of the 12 scholar "isolates" who had not yet published with other scholars were actually current scholars in the most recent cohort. These were in their second year of funding at the time of data collection and had not had time to publish extensively with other scholars. The Outward Bound experience helped contribute to that close networking of most of the scholars. The OB experience also received outstanding evaluations (reflecting the more formal evaluations started with the 2010 cohort) from the majority of the scholars as summarized in Table 3. We did have three scholars challenged by severe altitude sickness (one each year) in the first three cohorts when OB was held in Leadville, CO, which necessitated a change of locale to the Smokey Mountains in North Carolina. With the exception of one of the scholars with altitude sickness, all of the scholars who were able to attend strongly endorsed that the objectives were met (see Table 3).

Each year's experience was followed by use of the evaluations to plan the OB experience for the subsequent year with the OB staff. A few quotes from scholars about OB demonstrate the enthusiasm about the experience: "It was a life-changing experience for me. ... I overcame my 
greatest fears with the support of my friends. I will carry this confidence with me into my life, both personal and professional. I fully recognize that anything is possible; even those opportunities that you think are out of your reach, if you have the support and trust of those important around you. A united vision can be achieved." Also "I cannot think of a better way to allow members of the cohort to bond with one another, build collaborative teams, and learn leadership and team-building skills. The philosophy and pedagogy of OB really facilitates these" (see more quotes in Table 3).

\section{Subsequent Leadership Training}

The other domains of leadership training in addition to the aspects of Personal Development addressed in the Orientation Meeting, including Outward Bound, were addressed through national leadership training, and opportunities identified locally and regionally. The Personal Development aspects of the RWJF NFS that were presented and evaluated at subsequent sessions included expanding communication skills and further developing selfawareness through an interactive exercise of taping and receiving feedback from peers and a professional PR team. RWJF engaged PR Solutions (http://www.prsolutionsdc.com/) as consultants for NFS about their “elevator message" regarding RWJF's funded research (See Table 4 for more details on the Self-Presentation Taping Exercise with evaluation data). The Managing Time and Energy and Sustaining Career Optimism and Thriving in Changing Conditions topics were addressed through presentations by Angela Barron McBride and Beverly Malone ("The Zig Zag Career") followed by discussion at different trainings, as well as through mentoring by scholars' primary and national mentors and their peers. The National Program Director also provided a great deal of personal advice on career transitions over the course of the 
program. Evaluating progress on the IDP was done by obtaining feedback from mentors at the annual meeting and all scholars had to present formally on their IDP progress in the second year of their program. The presentations at the National Meeting of scholars' research (cohorts in their first and third years) were also designed to obtain maximum constructive feedback as well as serving an evaluative function.

The next domain was Leadership Skills for Research and Scholarship. As stated in the curriculum matrix, "scholars will work with institutional mentors and through self-identified learning opportunities to further strengthen research skills in their areas of expertise." The leadership training also provided technical assistance to develop and refine scholarly communication skills for publishing; for giving and getting criticism; writing effective proposals; refocusing and reframing one's work to meet a changing funding environment; and resubmission of proposals and publications. The program sought not to repeat what would be included in predoctoral and post-doctoral research training, but to focus on what tenure-probationary faculty are likely to face, thus the emphasis was less on writing first drafts and more on knowing how to revise after feedback has been obtained. The program also addressed strategies for building an interdisciplinary network and providing leadership in conducting culturally competent research. The funding from the program, including considerable support of time (60\%), also allowed scholars to take advantage of research skill offerings in their institution and nationally. Multiple scholars attended the NINR "Summer Genetics Institute" and also applied for and were accepted to other NIH advanced research summer institute training sessions (e.g., Grant Writing).

The third domain was Management Skills for Academic Leadership. Again through institutional mentorship and NFS leadership training, scholars refined their communication skills 
for effective self-presentation (through the interactive taping session and through being asked to present group work, innovative teaching methods and other leadership training sessions); to fine tune their ability to provide leadership in groups (at their own institutions and at the leadership trainings); organize people and resources to achieve predetermined objectives; understand financial procedures and how to leverage resources for themselves and for their schools; effectively manage grants; and participate/lead in strategic planning and development. One assignment required scholars to find out more about their school's budget-how much of the resources available were state appropriation, tuition dollars, grant monies, philanthropic donations, entrepreneurial profits and the like; the exercise wasn't meant for them to learn to be deans but to have them appreciate how faculty could provide leadership in generating resources and in understanding what was available for faculty support and how those resources could be enhanced.

The next domain was Leadership in Health Policy and/or Nursing Practice Arenas. "The RWJF NFS program will provide technical assistance and program content to understand the 'big picture 'of health policy and/or nursing practice arenas." The elements of this component included gaining an understanding of how academic nurse leaders can influence health policy, philanthropy, effective board behavior, and future trends. Table 4 shows several of the objectives of the Health Policy leadership training. This training was always held in Washington, DC. It utilized a nurse, the RWJF Health Policy Fellows National Program Director Marie Michnich, to organize and provide that training. The training also included time at the National Academy of Medicine (formerly Institutes of Medicine) with sessions on how that organization works and influences policy, as well as a homework assignment that scholars would arrange to come to DC for an extra day. At that time, they would meet with one of their congressional representatives 
and another policy entity in DC related to their area of research expertise (e.g. at NIH or elsewhere in DHHS). A webinar on how to do the congressional visit was held ahead of the meeting and a debriefing of their experience occurred during the meeting.

Our next domain was Skills for Teaching Excellence. The RWJF Nurse Faculty Scholars were expected to evaluate, further develop and improve their abilities in instructional techniques (including technology enhanced learning); develop curricula and programs; present on their educator role; assess and evaluate; mentor; and teach cultural competence and/or social determinants of health. Scholars also were expected to provide leadership in addressing the profession's commitment to ethnic, racial and gender diversity in their teaching, faculty and student recruitment practices. They also contributed to the integration of practice, education, and research in evidenced-based practice, incorporating knowledge of trends that are reshaping education, including interdisciplinarity.

The final domain was Leadership in the University Community and Profession. We planned that by the end of the program, scholars would have expanded their leadership role as university citizens by demonstrating an understanding of organizational structure and decisionmaking; participating in campus strategic planning; involvement in interdisciplinary research; demonstrating the ability to partner, negotiate, encourage and embrace diversity; and manage conflict. It was also expected that scholars would progress toward leadership in professional organizations.

\section{Formative Evaluations as the Basis for Improvements over Time}

Evaluations of a few of the leadership training meetings are also shown in Table 4. We made improvements based on scholar and NAC input after each meeting, just as we did for the 
Outward Bound experience. We also solicited input from primary mentors at the National Meetings as the program went on, setting aside an interactive session with them when we asked and received suggestions as to how to improve the program. Each leadership training meeting involved an interactive planning process starting with the National Program Office, NAC Chair and RWJF Program Officer. We also added a scholar planning committee in 2010 consisting of volunteers from each cohort that would be attending the meeting to improve the offerings over time by helping plan and implement the leadership training. We also increasingly used current Nurse Faculty Scholars and alumni to augment and present content and used more interactive presentation techniques (such as additional small group work, interactive panels, a "speed dating" technique of presentations or exemplars of innovative teaching strategies that small groups of scholars could choose among to attend).

We involved a variety of voices at each meeting - from different disciplines in addition to nursing, from research intensive and less research intensive universities, from the deans of the schools of nursing geographically close to where we held the meeting (rotating among East coast, West coast and Central US). We also had leading national experts on the topic of the training, some from our own NAC and some suggested by them and others as well as increasingly our own alumni as they developed relevant expertise.

Our National Meetings always included leadership training (Day 1) with the topic depending on where we were in the curriculum matrix. The process of scholar presentations and feedback is described in the Overview of the Program article in this issue as well as is the National Advisory Committee meeting held after the National Meeting that was used for ongoing evaluation and course corrections of the leadership training as well as the overall program. It was 
beneficial to offer each of the leadership training domain content sessions three times. This allowed us to learn more each time it was presented; to employ more useful content delivery strategies (e.g., more interactive sessions); incorporate more self-presentation and small group leadership opportunities; have additional current and alumni scholars involved in both the planning and content delivery; and retain and find the most effective speakers using new thinking and ideas on leadership as we continued through the program.

\section{Summary and Conclusions}

In summary, the RWJF NFS leadership training process, delivery and outcomes have many lessons to offer for use in future leadership training programs for nursing faculty. The importance of in-person trainings; online content; interactive delivery; learning from peers and interdisciplinary experts; and using a cohort bonding and challenge experiential learning are lessons that can be transferred to other programs. The domains covered by this program could easily be used as a framework to plan leadership-development programs over the course of a new faculty member's first and/or second year. Too often leadership training programs assume that all assigned mentors will have the same expectations in mind and be equally skilled, however we found that involving mentors in the orientation then asking for their feedback annually ensured that would be the case.

Quotes about the program from scholars from both research intensive (level of NIH research funding $>\$ 1.5$ million) and less research intensive (level of NIH research funding $\leq$ $\$ 1.5$ million) schools best summarize the cumulative outcomes. The following quotes are from alumni that participated in the program from less research intensive schools. "The program challenged me to take on new roles and responsibilities - expanding my research with basic science, providing strategic program leadership, building relationships with nursing leaders 
around the country. It emboldened me as a health advocate and strengthened my passion for creating healthy environments. I now have a vision for how I can contributing to building a culture of health.” (E. Alison Holman, RWJF NFS 2010 Cohort; Associate Professor, University of California, Irvine, Program in Nursing Science) "Starting with Outward Bound, the RWJF NFS program encouraged us to move from our comfort zones into our stretch zones - and that definitely happened for me! Most valued, I never felt as if I was out on a limb alone, with the program's built-in structures for mentorship from three extraordinary leaders, each with distinctly different mentoring roles. This key component of the program was core to my professional development as I considered and reflected on new opportunities, taking risks, leveraging resources, and overcoming challenges!” (Elena Siegel, RWJF NFS 2011 Cohort, Associate Professor, University of California, Davis Betty Irene Moore School of Nursing).

Quotes from scholars in more research intensive schools further demonstrates the successful collective outcomes of the program. "The RWJF NFS program's leadership component shaped me and allowed me to create a vision and strategic approach to leadership that far exceeded my initial capacity. The leadership training combined with multilevel mentoring, networking and sincere personal support from the NAC were all phenomenal and prepared me to walk with confidence into new leadership roles now and in the future." (Yolanda Ogbolu, RWJF NFS 2013 Cohort, Associate Professor, University of Maryland School of Nursing) "I'm two years past the end of the program and I still call cohort members for advice.... Weaving together the interpersonal relationships with the leadership development was brilliant." (Sarah Szanton, RWJF NFS 2011 Cohort, Associate Professor, Johns Hopkins University School of Nursing) "I have participated in several leadership training programs over my time as a young scholar. The RWJF NFS is different because of the critical timing of the program in the years leading up to 
promotion and tenure (the funding itself "counted" when I went up), and the design of the national program meetings to "check in" with scholars. It was important to have the national program meet twice a year because it was helpful to present my work and get external validation for my progress. When you are in the day-to-day trenches of the early research career it is easy to lose your optimism, and the program really helped with that." (Anna Beeber, RWJF NFS 2011 Cohort; Associate Professor, UNC Chapel Hill School of Nursing). And finally, "The program was an extraordinary chance to learn and work with the best and brightest emerging nurse leaders..... I was able to grow my program of research while also establishing myself as a wellrounded member of the larger university community. The program pushed us to see and realize the full impact we could have on research, policy, and practice as nursing faculty." (Matthew McHugh, RWJF NFS 2011 Cohort; Associate Professor, University of Pennsylvania School of Nursing)

Vicki Conn, the distinguished editor of the Western Journal of Nursing Research, praised this program because the central thrust was leadership development: "Although being successful in scholarly pursuits is a necessary aspect in gaining recognition as a leader within academic nursing, the program is about much more than supporting programs of research. A central program thrust is on building leadership capability" (2013, p. 1104). What set this program apart is that it went beyond offering the research support of a $\mathrm{K}$ award, and immersed junior faculty in concerted leadership development with regard to all aspects of the faculty role so that teaching interactively, making use of the latest in information technology, giving testimony before a policy-making group, participating in strategic planning, and figuring out how to reduce the budget without jeopardizing quality were all envisioned as part of the faculty role. In the past, we have regarded many of these skills as the sole province of deans and other administrators, but 
increasingly all faculty are being asked to exert such leadership for the sake of their students, their universities, our profession, and the American public. Today's challenges are so great that administrators will only be able to address them successfully if they can work collegially with faculty who understand the larger forces shaping academia.

Even if you don't have available the resources of the RWJF NFS Program, schools of nursing can do a better job of preparing junior faculty to be $21^{\text {st }}$-century academic leaders by offering their version of over-time leadership training covering the domains summarized in the curriculum matrix and involving in-house mentors, alumni and content experts. Such a program can be a way of helping new faculty bond with each other; encouraging faculty mentors to proceed from shared values; demonstrating an ongoing commitment to the tripartite university mission; and communicating an institutional commitment to faculty development. Many schools already have elements of such a program—an orientation for new faculty, assigned mentors, small grant monies for pilot studies, programming offered by the research office, monthly overlunch discussions about how to encourage interactive learning — but value is added when all of the elements are repackaged as part of a larger whole committed to the individual's development as an essential ingredient in the achievement of institutional pre-eminence. Better yet, such overtime leadership training may be even more successful if it takes place at the university level, so inter-professional bonding can be encouraged! 


\section{References:}

American Association of Colleges of Nursing (AACN). (2010). The research-focused doctoral program in nursing: Pathways to excellence. Retrieved from http://www.aacn.nche.edu/education-resources/PhDTaskForceReport.pdf

American Association of Colleges of Nursing (AACN). (2014). Special Survey On Vacant Faculty Positions For Academic Year 2014-2015. Retrieved from:

http://www.aacn.nche.edu/leading-initiatives/research-data/vacancy14.pdf

American Association of Colleges of Nursing (AACN). (2015). Nursing Faculty Shortage Fact Sheet. Retrieved from http://www.aacn.nche.edu/media-relations/FacultyShortageFS.pdf

Anderson, J. K. (2009). The work-role transition of expert clinician to novice academic educator. The Journal of Nursing Education, 48(4), 203. Retrieved from http://graphics.tx.ovid.com/ovftpdfs/FPDDNCFBPACCAA00/fs047/ovft/live/gv024/000 05111/00005111-200904000-00005.pdf

Baker, S. L., \& Baker, S. L. (2010). Nurse educator orientation: Professional development that promotes retention. The Journal of Continuing Education in Nursing, 41(9), 413-417. doi:10.3928/00220124-20100503-02

Campbell, J. and Sharps, P. (2016). Surviving and thriving: The integrated scholar model. Unpublished manuscript.

Conn, V.S. (2013). Preparing academic nursing's future leaders: The Robert Wood Johnson Foundation's Nurse Faculty Scholar Program. Western Journal of Nursing Research, 35, 1104-1106.

Conn, V. S., Porter, R. T., McDaniel, R. W., Rantz, M. J., \& Maas, M. L. (2005). Building research productivity in an academic setting. Nurs Outlook, 53(5), 224-231. doi:http://dx.doi.org/10.1016/j.outlook.2005.02.005

Davis, C. E. (2015). Understanding nursing faculty attrition. (3722153 Ph.D.), Keiser University, Ann Arbor. Retrieved from http://search.proquest.com/docview/1728057433?accountid=15172http://wa4py6yj8t.sear ch.serialssolutions.com/?ctx_ver=Z39.88-2004\&ctx_enc=info:ofi/enc:UTF8\&rfr_id=info:sid/ProQuest+Dissertations+\%26+Theses+Global\&rft_val_fmt=info:ofi/f mt:kev:mtx:dissertation\&rft.genre $=$ dissertations $+\% 26+$ theses $\&$ rft.jtitle $=\& r f t$.atitle $=\& r f t . a$ $\underline{\mathrm{u}}=$ Davis\%2C+Claudia+E.\&rft.aulast $=$ Davis\&rft.aufirst $=$ Claudia\&rft.date $=2015-01-$ 01\&rft.volume $=\&$ rft.issue $=\&$ rft.spage $=\&$ rft.isbn $=9781339040936 \&$ rft.btitle $=\&$ rft.title $=\mathrm{U}$ nderstanding+nursing+faculty+attrition\&rft.issn=\&rft_id=info:doi/ ProQuest Dissertations \& Theses Global database. 
Derby-Davis, M. J. (2014). Predictors of nursing faculty's job satisfaction and intent to stay in academe. Journal of Professional Nursing, 30(1), 19-25. doi:http://dx.doi.org/10.1016/j.profnurs.2013.04.001

Eagly, A.H. andCarli, L. L. (2007). Through the labyrinth: The truth about how women become leaders. Boston, MA: Harvard University Press.

Fagin, C. M., Franklin, P. D., Regenstreif, D. I., \& Huba, G. J. (2006). Overview of the John A. Hartford Foundation building academic geriatric nursing capacity initiative. Nurs Outlook, 54(4), 173-182. doi:http://dx.doi.org/10.1016/j.outlook.2006.05.008

Field, S. (2012). The Trials of transition, and the impact upon the pedagogy of new teacher educators. Professional Development in Education, 38(5), 811.

Froman, R. D., Hall, A. W., Shah, A., Bernstein, J. M., \& Galloway, R. Y. (2003). A methodology for supporting research and scholarship. Nurs Outlook, 51(2), 84-89. doi:http://dx.doi.org/10.1016/S0029-6554(02)05457-X

Garand, L., Matthews, J. T., Courtney, K. L., Davies, M., Lingler, J. H., Schlenk, E. A., Yang, K., Bender, C. M., \& Burke, L. E. (2010). Development and use of a tool to guide junior faculty in their progression toward promotion and tenure. Journal of Professional Nursing, 26, 4, 207-213.

Happell, B., \& Cleary, M. (2014). Research career development: The importance of establishing a solid track record in nursing academia. Collegian, 21(3), 233-238. doi:http://dx.doi.org/10.1016/j.colegn.2013.04.005

McBride, A. B. (2010). Toward a roadmap for interdisciplinary academic career success. Research and Theory for Nursing Practice, 24(1), 74-86.

McBride, A. B. (2011). The growth and development of nurse leaders. New York, NY: Springer Publishing.

Miller, L., Beck, C., Dowling, G., Herr, K., Maas, M., Naylor, M., \& Tripp-Reimer, T. (2006). Building gerontological nursing research capacity: Research initiatives of the John A. Hartford Foundation Centers of Geriatric Nursing Excellence. Nurs Outlook, 54(4), 189196. doi:http://dx.doi.org/10.1016/j.outlook.2006.04.005

Millett, C. M., Millett, C. M., \& Kevelson, M. J. C. (2015). A study of the influence of the new careers in nursing program on the culture of participating schools of nursing. ETS Research Report Series, 2015(2), 1-39. doi:10.1002/ets2.12077

Mobily, P. R. (1991). An examination of role strain for university nurse faculty and its relation to socialization experiences and personal characteristics. The Journal of Nursing Education, $30(2), 73$. 
Reece, E. A., Nugent, O., Wheeler, R. P., \& Smith, C. W. (2008). Adapting industry-style business model to academia in a system of performance-based incentive compensation. Academic Medicine, 83(1), 76-84. doi:10.1097/ACM.0b013e31815c6508

Wilson, L. A., Crooks, E. A., Day, S. W., \& Dawson, M. A. (2014). Global perspectives on nursing leadership: Lessons learned from an international nursing and health care leadership development program. Journal of nursing education and practice, 4(2), 140140. 
Figure 1 - Integrated Scholar Model

Faculty Roles: Usually in Separate Spheres

Integrated Scholar Model—Overlap Your Roles Around Your Passion-Your Area of Expertise and Excitement

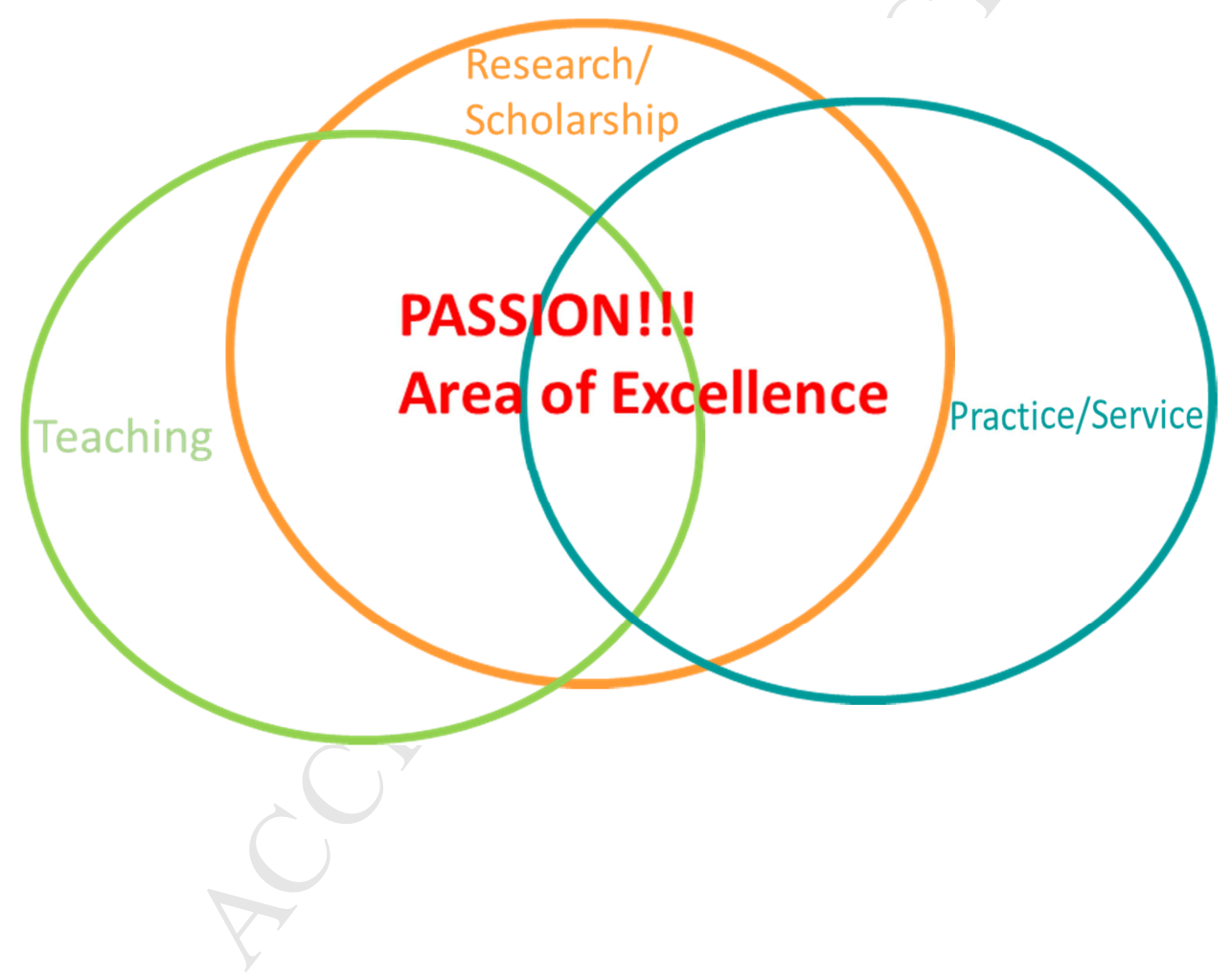


Table 1: RWJF NFS Curriculum Matrix Overview. The RWJF NFS curriculum matrix describes the competencies that scholars are expected to achieve; the program content provided in NFS leadership training; technical assistance including assignments to be carried out locally and directions to other venues by which scholars can get needed training; and program metrics. It is organized by six domains summarized below (Full Curriculum Matrix Available from the RWJF NFS National Program Office):

- Personal development:

- Self-awareness,

- Energy Management

- Sustained Career Optimism

o Work-life balance

- Expanded communication skills.

- Leadership Skills for Research and Scholarship:

$\circ$ Writing and rewriting for publication

$\circ$ Giving and getting criticism,

- Writing and resubmitting effective proposals,

- Refocusing and reframing one's work to meet a changing funding environment,

○ Strategies for building an interdisciplinary network

- Leadership in conducting culturally competent research.

- Management Skills for Academic Leadership:

$\circ$ Refine communication skills for effective self-presentation

- Provide leadership in groups,

- Organize people and resources to achieve predetermined objectives,

- Understand financial procedures and how to leverage resources,

- Effectively manage grants,

○ Participate/lead in strategic planning and development.

- Leadership Skills in Health Policy and/or Nursing Practice Arenas:

○ Understand the "big picture" of health policy and/or nursing practice arenas. Influence health policy in multiple arenas (professional organizations, philanthropy, health policy forums

- Leadership through board membership and effective board behavior.

- Skills for Teaching Excellence: Nurse Faculty Scholars are expected to evaluate, further develop and improve their abilities and leadership in:

$\circ$ Innovative instructional techniques, creative pedagogy,

- Curriculum and program development, assessment and evaluation,

○ Mentoring

- Teaching cultural competence.

- Addressing commitment to ethnic, racial and gender diversity and inclusion across roles

○ Leadership in trends reshaping education e.g. evidenced-based practice based on research, interdisciplinarity/interprofessional education; teaching social determinants of health)

- Evolving leadership in the University, Community and Profession:

○ University organizational structure and decision-making;

- Leadership roles in campus and other organization strategic planning; 
Interdisciplinary research and team science

Leadership in professional organizations. 


\begin{tabular}{|c|c|c|c|c|c|}
\hline Topic/Module & Competency & Institutional Level & Metric & National Level & Metric \\
\hline \multicolumn{6}{|c|}{ Personal Development } \\
\hline $\begin{array}{l}\text { Open to } \\
\text { Opportunities }\end{array}$ & $\begin{array}{l}\text { Be open to opportunities-in discipline and } \\
\text { beyond discipline. } \\
\text { Dispel the Myths: Do certain things in certain } \\
\text { order; get away from sacredness of certain } \\
\text { experiences; learn difference between } \\
\text { learning from experience vs. leadership } \\
\text { training }\end{array}$ & $\begin{array}{l}\text { Map career path } \\
\text { Cost-benefit analysis of } \\
\text { opportunities } \\
\text { Through the Labyrinth- } \\
\text { book assignment. } \\
\text { Take on leadership } \\
\text { opportunities at school, } \\
\text { institution }\end{array}$ & $\begin{array}{l}\text { Membership in a } \\
\text { relevant, key } \\
\text { interdisciplinary } \\
\text { organization at } \\
\text { institutional \&/or local }\end{array}$ & $\begin{array}{l}\text { Preparation as effective } \\
\text { board member- } \\
\text { effective committee } \\
\text { member }\end{array}$ & $\begin{array}{l}\text { Membership/leader } \\
\text { ship in a relevant, } \\
\text { key national or } \\
\text { regional } \\
\text { interdisciplinary } \\
\text { organization }\end{array}$ \\
\hline \multicolumn{6}{|c|}{ Leadership Skills for Research and Scholarship } \\
\hline Collaboration & $\begin{array}{l}\text { Develop or maintain an interdisciplinary } \\
\text { collaborative network with other researchers, } \\
\text { clinicians, and policymakers }\end{array}$ & $\begin{array}{l}\text { Work with mentors to } \\
\text { identify potential } \\
\text { collaboration }\end{array}$ & $\begin{array}{l}\text { Demonstrated } \\
\text { collaboration }\end{array}$ & $\begin{array}{l}\text { National collaboration } \\
\text { formation-across } \\
\text { RWJF cohorts, national } \\
\text { mentors, others }\end{array}$ & $\begin{array}{l}\text { Funding, } \\
\text { publications; } \\
\text { network analysis }\end{array}$ \\
\hline \multicolumn{6}{|c|}{ Management Skills for Academic Leadership } \\
\hline Negotiation skills & $\begin{array}{l}\text { Prepare for and adequately manage a } \\
\text { resource-based negotiation }\end{array}$ & $\begin{array}{l}\text { Lead negotiation } \\
\text { relevant to one's } \\
\text { research portfolio }\end{array}$ & $\begin{array}{l}\text { Self-report of an actual } \\
\text { negotiation, critical } \\
\text { evaluation, SON } \\
\text { mentor report }\end{array}$ & $\begin{array}{l}\text { Negotiation training; } \\
\text { Leadership Strategies } \\
\text { for Identity, Reputation } \\
\text { and Legacy } \\
\text { Management }\end{array}$ & $\begin{array}{l}\text { Presentation of IDP } \\
\text { at National Meeting } \\
\text { in Year } 2 \text { showing } \\
\text { negotiation success }\end{array}$ \\
\hline \multicolumn{6}{|c|}{ Leadership in Nursing Education } \\
\hline $\begin{array}{l}\text { Diversity in } \\
\text { Academic } \\
\text { Nursing }\end{array}$ & $\begin{array}{l}\text { Demonstrates a commitment to ethnic, racial } \\
\text { and gender diversity in academic nursing; } \\
\text { Articulate and measure the advantages of } \\
\text { diversity in research teams, being at a diverse } \\
\text { SON, and value-added of a diverse } \\
\text { institution; } \\
\text { Recruit a diverse student body and faculty; } \\
\text { Effectively promote a culture of inclusion and } \\
\text { community development within one's } \\
\text { institution; } \\
\text { Appreciate the value of diversity of thought }\end{array}$ & $\begin{array}{l}\text { Review own teaching for } \\
\text { effectiveness of teaching } \\
\text { to a diverse audience; } \\
\text { Develop learning plan } \\
\text { around diversity actions } \\
\text {-those from majority } \\
\text { group step up and "own" } \\
\text { diversity; } \\
\text { Address racial privilege }\end{array}$ & $\begin{array}{l}\text { Course syllabi: } \\
\text { cultural competence in } \\
\text { nursing care; } \\
\text { Demonstrated success } \\
\text { of recruitment of } \\
\text { diverse faculties and } \\
\text { student bodies; } \\
\text { Member of SON, } \\
\text { University Diversity } \\
\text { Committees }\end{array}$ & $\begin{array}{l}\text { Strategies for } \\
\text { recruitment of diverse } \\
\text { student body and } \\
\text { diverse faculty }\end{array}$ & $\begin{array}{l}\text { On profession } \\
\text { Diversity } \\
\text { Committees Task } \\
\text { Forces, reports; } \\
\text { Funding for } \\
\text { diversity enhancing } \\
\text { educational } \\
\text { initiatives }\end{array}$ \\
\hline \multicolumn{6}{|c|}{ Leadership in the University Community } \\
\hline $\begin{array}{l}\text { Serving as a team } \\
\text { member in } \\
\text { resolution of } \\
\text { issues }\end{array}$ & $\begin{array}{l}\text { Demonstrate the ability to partner, negotiate, } \\
\text { encourage diversity and manage conflict in } \\
\text { teams; } \\
\text { Identify and engage in interdisciplinary }\end{array}$ & $\begin{array}{l}\text { Learning "good } \\
\text { meeting" behaviors }\end{array}$ & $\begin{array}{l}\text { Demonstrate capacity } \\
\text { to chair meetings } \\
\text { effectively }\end{array}$ & $\begin{array}{l}\text { Team challenge } \\
\text { meeting activities at } \\
\text { OB; Small group } \\
\text { problem solving }\end{array}$ & $\begin{array}{l}\text { Social network } \\
\text { analysis }\end{array}$ \\
\hline
\end{tabular}


Table 3: Selected Outward Bound Training Evaluations(Evaluations were open-ended questions)

\section{Evaluation Questions Ratings}

Has the OB experience contributed to the development of leadership skills and to $(\mathrm{N}=41)$ your growth as an academic leader?

Was the OB experience useful for developing team skills and awareness?

$97.6 \%$

(yes); $2.4 \%$

(no)

$(\mathrm{N}=41)$

Comment on the usefulness of the different components of your OB experience in developing awareness and understanding of your personal leadership style.

After reflecting on your experience, is there anything you

\section{Quotes}

"I think this is hard to know after just a few days and that it might sink in surprising ways over time. I definitely came home feeling (yes); $2.4 \%$ committed to hiring and collaborating with other types of people who are more pessimistic and detail-oriented because I can see that even (no) though I am drawn to optimistic conceptual people, I have to think as though I am building a small business.'

$$
\text { (2) }
$$

"I feel like I leave this experience with a very clear picture of my strengths and challenges as a leader. I also have a beginning repertoire (which I intend to build on) of measures to take to address these challenges and to maximize strengths."

"This was amazing for team building and awareness. We all worked together so hard these past few days that I feel a tremendous connection with them that I know will continue beyond this program."

"Our Outward Bound experience reminded me and reinforced the notion that a team can come together during times of stress and anxiety, and the sense of team can actually become stronger as a result of team members' expressions of their stress and anxiety.... So, the take-home message for me is that team members' stress/anxiety can be positive forces for a team's cohesiveness, but it doesn't happen by accident. I need to examine and develop leadership skills to support my teams (as a team leader or team member) to come together during challenging situations."

"Each Outward Bound Experience was useful for developing awareness and understanding of my personal leadership style and team building.... the value was in the collective and varied experiences, across the different components...I watched the ebb and flow of team members stepping up to lead the way and offer their skills and strengths to support others.... Having this time to reflect and consider our leadership/team roles in settings outside of the comfort of our known worlds was an invaluable opportunity for my own professional development.... team building exercises (indoor activities)... were powerful opportunities to identify subtle leadership and team building challenges that can occur when overall goals are unclear or interpreted differently among the team members.="

"Lots of heated discussion/conflict the night before. It gave us an opportunity to experience conflict in a setting where we could work through it, the conflict, to a satisfactory outcome. As we completed the peak ascend we were able to see how much success is possible when a group of people work together towards a common goal."

"Once on the trail, it became clear how you must trust your leaders (navigators) to take over (even though you think you could do it yourself). We made some important decisions as a group, we made some mistakes and had some accomplishments. We kept in mind our team goals (that were established in the beginning) to make the trip fun and challenging."

N/A "The most significant transformation for me has been to realize importance of being sensitive to differences in how people react and process information. This realization is helping me to be more patient and understanding in working with my research team members at work and in other group forums such as faculty meetings." 
would like to add

about a change or new

awareness that might

have occurred for you?

Would you

recommend that NFS

continue to sponsor

$\mathrm{OB}$ as part of the next

NFS orientation?
"It was a life-changing experience for me. As I look at my pictures (daily) and consider the amazing friendships that developed over a very short period of time, I am truly amazed. I overcame my greatest fears with the support of my friends. I will carry this confidence with me into my life, both personal and professional. I fully recognize that anything is possible; even those opportunities that you think are out of your reach, if you have the support and trust of those important around you. A united vision can be achieved."
$97.6 \%$

(yes); $2.4 \%$

(no)

$(\mathrm{N}=41)$
"I cannot think of a better way to allow members of the cohort to bond with one another, build collaborative teams, and learn leadership and team-building skills. The philosophy and pedagogy of OB really facilitates these."

"Taking us out of our comfort zone and putting us with a group of people we did not know and have us work in a team was brilliant. It was a surefire way of getting us acquainted on a very personal level that created bonds that will last a lifetime." 
Table 4. Selected Leadership Training Evaluations - one objective from three content areas; quotes represent one positive; one negative or suggestion for change

\begin{tabular}{|c|c|c|c|c|c|}
\hline Objectives: & $\begin{array}{ll}\text { - } & \text { To develop multi- } \\
\text { research descriptic } \\
\text { - To increase know } \\
\text { - To understand the } \\
\text { - To increase know } \\
\text { fiscal challenges o }\end{array}$ & $\begin{array}{l}\text { imensional skills for effecti } \\
\text { with critique from PR firm } \\
\text { dge about health policy forr } \\
\text { ole of health policy-orientec } \\
\text { dge about school and unive } \\
\text { schools of nursing in both }\end{array}$ & $\begin{array}{l}\text { e self-presentation as an academic } \\
\text { ation (Policy) } \\
\text { nursing and interprofessional stak } \\
\text { ity finances and nursing faculty l} \\
\text { ivate and public universities }\end{array}$ & $\begin{array}{l}\text { nurse leader (Self-Present } \\
\text { eholder groups } \\
\text { adership roles in building }\end{array}$ & $\begin{array}{l}\text { tion) - used a videotaped } \\
\text { he resource base and address }\end{array}$ \\
\hline Content & $\begin{array}{l}\text { Self-Presentation: } \\
\text { representing academic } \\
\text { nursing and nursing } \\
\text { research to the media } \\
(2009 ; 2012 ; 2015)\end{array}$ & $\begin{array}{l}\text { Overview of Health } \\
\text { Policy Formation } \\
(2010 ; 2013 ; 2016)\end{array}$ & $\begin{array}{l}\text { Policy Formation through } \\
\text { Nursing and Interprofessional } \\
\text { Stakeholder Groups } \\
(2010 ; 2013 ; 2016)\end{array}$ & $\begin{array}{l}\text { The Role of the } \\
\text { Academic Nurse } \\
\text { Leader in University } \\
\text { Finances and in } \\
\text { Fiscally Challenging } \\
\text { Situations (2009; 2012; } \\
\text { 2015) }\end{array}$ & $\begin{array}{l}\text { Policy Formation "On the } \\
\text { Hill”" } \\
(2010 ; 2013 ; 2016)\end{array}$ \\
\hline $\begin{array}{l}\text { First-Year Evaluation } \\
\text { Summary }\end{array}$ & $\begin{array}{l}\text { Open-ended evaluation } \\
\text { questions only }\end{array}$ & $\begin{array}{l}4.2 \% \text { moderately useful; } \\
16.7 \% \text { useful; } 79.2 \% \text { very } \\
\text { useful }(\mathrm{N}=24)\end{array}$ & $\begin{array}{l}4.2 \% \text { not useful; } 12.5 \% \\
\text { moderately useful; } 16.7 \% \\
\text { useful; } 66.7 \% \text { very useful } \\
(\mathrm{N}=24)\end{array}$ & $\begin{array}{l}20 \% \text { moderately useful; } \\
35 \% \text { useful; } 45 \% \text { very } \\
\text { useful }(\mathrm{N}=20)\end{array}$ & $\begin{array}{l}4.2 \% \text { moderately useful; } \\
41.7 \% \text { useful; } 54.2 \% \text { very } \\
\text { useful }(\mathrm{N}=24)\end{array}$ \\
\hline $\begin{array}{l}\text { First-Year } \\
\text { Representative Scholar } \\
\text { Quotes }\end{array}$ & $\begin{array}{l}\text { "more work on individual } \\
\text { messages" }\end{array}$ & $\begin{array}{l}\text { "the whole session was } \\
\text { amazing. I loved hearing } \\
\text { the stories, loved seeing } \\
\text { smart, energetic nurses } \\
\text { (mostly!) talk about } \\
\text { policy" } \\
\text { "more about application } \\
\text { of this experience for } \\
\text { scholars would have been } \\
\text { helpful" }\end{array}$ & $\begin{array}{l}\text { "I thought the moderator was } \\
\text { wonderful in preparing for the } \\
\text { presentation, being provocative } \\
\text { which was his charge...the } \\
\text { ability to question is the only } \\
\text { way we will advance...I } \\
\text { enjoyed the exchange" } \\
\text { "discussion between members } \\
\text { was helpful/question(s) from } \\
\text { scholars was helpful to see } \\
\text { how various panel members } \\
\text { responded" }\end{array}$ & $\begin{array}{l}\text { "eye opening } \\
\text { information on budget } \\
\text { managing and budget } \\
\text { cuts" } \\
\text { "would have liked to } \\
\text { make some } \\
\text { comparisons to own } \\
\text { experiences" }\end{array}$ & $\begin{array}{l}\text { "it was good to learn about } \\
\text { what is important to } \\
\text { politicians and policy- } \\
\text { makers-that is not always } \\
\text { the evidence or data, but how } \\
\text { public opinion plays a big } \\
\text { role in decision- making" } \\
\text { "long introduction of their } \\
\text { speakers [was least useful]" }\end{array}$ \\
\hline $\begin{array}{l}\text { Second-Year } \\
\text { Evaluation Summary }\end{array}$ & $\begin{array}{l}3.70 \% \text { not useful; } 7.41 \% \\
\text { moderately useful; } \\
85.19 \% \text { very useful } \\
(\mathrm{N}=27)\end{array}$ & $\begin{array}{l}13.8 \% \text { useful; } 86.2 \% \text { very } \\
\text { useful }(\mathrm{N}=29)\end{array}$ & $\begin{array}{l}6.9 \% \text { moderately useful; } 31 \% \\
\text { useful; } 62.1 \% \text { very useful } \\
(\mathrm{N}=29)\end{array}$ & $\begin{array}{l}11.1 \% \text { moderately } \\
\text { useful; } 22.2 \% \text { useful; } \\
60 \% \text { very useful } \\
(\mathrm{N}=18)\end{array}$ & $\begin{array}{l}24.1 \% \text { useful; } 75.9 \% \text { very } \\
\text { useful }(\mathrm{N}=29)\end{array}$ \\
\hline $\begin{array}{l}\text { Second Year } \\
\text { Representative Scholar } \\
\text { Quotes }\end{array}$ & $\begin{array}{l}\text { "I truly hate to be in front } \\
\text { of the camera, but now I } \\
\text { have strategies on how to }\end{array}$ & $\begin{array}{l}\text { "very practical" } \\
\text { "very useful in describing }\end{array}$ & $\begin{array}{l}\text { "The engaging style of Dr. } \\
\text { Reum and how he drew out } \\
\text { each panel member. This is }\end{array}$ & $\begin{array}{l}\text { "the opportunity to } \\
\text { work as a small group } \\
\text { to address the financial }\end{array}$ & $\begin{array}{l}\text { "this was an outstanding } \\
\text { session...she literally made } \\
\text { me want to run to }\end{array}$ \\
\hline
\end{tabular}




\begin{tabular}{|c|c|c|c|c|c|}
\hline & $\begin{array}{l}\text { present myself with } \\
\text { presence and tools to } \\
\text { handle different types of } \\
\text { media outlets. This } \\
\text { session was invaluable" } \\
\text { "I do not like } \\
\text { media/recording/review } \\
\text { in such a large group. I } \\
\text { would prefer a smaller } \\
\text { group next time" }\end{array}$ & $\begin{array}{l}\text { how to frame research } \\
\text { findings for } \\
\text { policymakers...really } \\
\text { appreciated her mini-talk } \\
\text { on the differences } \\
\text { between academics and } \\
\text { policymakers" }\end{array}$ & $\begin{array}{l}\text { how a panel should be done! It } \\
\text { was amazing and very } \\
\text { engaging" } \\
\text { "I would have liked the } \\
\text { panelists to have even } 5 \\
\text { minutes to make an } \\
\text { introduction and talk about } \\
\text { their work" }\end{array}$ & $\begin{array}{l}\text { problems and make } \\
\text { decisions [was most } \\
\text { useful]. The expert } \\
\text { person in my group was } \\
\text { also very helpful in } \\
\text { guiding us through the } \\
\text { process" } \\
\text { "could have used more } \\
\text { time" }\end{array}$ & $\begin{array}{l}\text { Washington to influence } \\
\text { policy" } \\
\text { "great stories, interactive" }\end{array}$ \\
\hline $\begin{array}{l}\text { Last-Year Evaluation } \\
\text { Summary }\end{array}$ & $\begin{array}{l}4.17 \% \text { moderately useful; } \\
4.17 \% \text { useful; } 91.67 \% \\
\text { very useful }(\mathrm{N}=24)\end{array}$ & $\begin{array}{l}16.67 \% \text { useful; } 83.33 \% \\
\text { very useful }(\mathrm{N}=12)\end{array}$ & $\begin{array}{l}41.67 \% \text { useful' } 58.33 \% \text { very } \\
\text { useful }(\mathrm{N}=12)\end{array}$ & $\begin{array}{l}8.33 \% \text { moderately } \\
\text { useful; } 16.67 \% \text { useful; } \\
75 \% \text { very useful } \\
(\mathrm{N}=12)\end{array}$ & $\begin{array}{l}8.33 \% \text { moderately useful; } \\
91.67 \% \text { very useful }(\mathrm{N}=12)\end{array}$ \\
\hline $\begin{array}{l}\text { Last-Year } \\
\text { Representative Scholar } \\
\text { Quotes }\end{array}$ & $\begin{array}{l}\text { "loved the taping and } \\
\text { critique; it was interactive } \\
\text { and informative" } \\
\text { "I think this caused } \\
\text { anxiety in some scholars. } \\
\text { But everyone overcame it } \\
\text { well" }\end{array}$ & $\begin{array}{l}\text { "the opportunity for lots } \\
\text { of discussion with the } \\
\text { audience [was most } \\
\text { useful]" } \\
\text { "her overall experience } \\
\text { and expertise along with } \\
\text { informal presentation } \\
\text { style were just } \\
\text { phenomenal, I learned so } \\
\text { much!!!!" }\end{array}$ & $\begin{array}{l}\text { "This was one of the best } \\
\text { sessions. The facilitator was } \\
\text { excellent, the panelists were } \\
\text { open and honest, and everyone } \\
\text { in the room was an active } \\
\text { participant. It was a fun way to } \\
\text { end" } \\
\text { "The different perspectives } \\
\text { were fantastic and given their } \\
\text { diversity made it that much } \\
\text { better" }\end{array}$ & $\begin{array}{l}\text { "this was a very well } \\
\text { thought out and helpful } \\
\text { session and loved the } \\
\text { group work aspect of } \\
\text { this" } \\
\text { "the case study was a } \\
\text { bit challenging, in that } \\
\text { there were pieces of } \\
\text { information we would } \\
\text { have liked to have, but } \\
\text { did not have" }\end{array}$ & $\begin{array}{l}\text { "hearing the different } \\
\text { perspectives of experienced } \\
\text { leaders from within and } \\
\text { outside government" } \\
\text { "excellent representation of } \\
\text { how a clinical practice and } \\
\text { area of research translates to } \\
\text { policy" }\end{array}$ \\
\hline
\end{tabular}




\section{Robert Wood Johnson Foundation Nurse Faculty Scholars Program Leadership Training}

- NAC development of a curriculum matrix-what does the $21^{\text {st }}$-century nursing faculty member need to know?*

- Pedagogical considerations-interactive learning, scholar/NAC involvement

- Specifics regarding leadership positions assumed by scholars*

- Lessons learned that can be applied in other situations

- Experiential leadership training through Outward Bound

*asterisk indicates that article would contain data obtained as part of evaluation efforts 